\title{
Rekonstruksi Bahan Ajar dengan Konteks Socio-Scientific Issues pada Materi Zat Aditif Makanan untuk Meningkatkan Literasi Sains Siswa
}

\author{
Diana Ayu Rostikawati ${ }^{1}{ }^{*}$, Anna Permanasari ${ }^{2}$ \\ ${ }^{12}$ Pendidikan IPA, Sekolah Pascasarjana, Universitas Pendidikan Indonesia. Jalan Dr. Setiabudhi No. \\ 229 Bandung 40154 Jawa Barat, Indonesia \\ * Korespondensi Penulis. Email: dianarostikawati@gmail.com, Telp. 022-2013163
}

\begin{abstract}
Abstrak
Tujuan dari penelitian ini adalah untuk mengetahui hasil rekonstruksi, penilaian, implementasi, dan tanggapan siswa terhadap bahan ajar dengan konteks SSI pada materi zat aditif makanan yang dihasilkan melalui penerapan model rekonstruksi pendidikan. Penelitian ini dilakukan dengan metode R\&D dan desainnya adalah Model of Educational Reconstruction yang dimodifikasi.Bahan ajar dengan konteks SSI pada materi zat aditif makanan yang telah dikembangkan terdiri atas delapan sub bab. Setiap sub bab memuat deskripsi materi, daftar bacaan tambahan dan soal latihan. Penilaian bahan ajar dilakukan dengan 2 cara, yaitu validasi berdasarkan kriteria umum dan penilaian berdasarkan kriteria Badan Standar Nasional Pendidikan (BSNP). Hasil penilaian menunjukkan bahan ajar sudah layak dan memenuhi syarat untuk digunakan dalam proses pembelajaran IPA di kelas VIII SMP. Hasil implementasi menunjukkan bahwa bahan ajar memiliki pengaruh yang besar dan dapat meningkatkan literasi sains siswa baik pada aspek kompetensi maupun sikap.Tanggapan siswa menunjukkan bahwa bahan ajar dengan konteks SSI pada materi zat aditif makanan sudah dipahami dan memenuhi harapan belajar siswa.
\end{abstract}

Kata Kunci:bahan ajar,model of educational reconstruction, socio-scientific issues (SSI), zat aditif makanan, literasi sains

\section{Reconstruction of Learning Materials with Socio-Scientific Issues Context on Food Additives Content to Improving Student's Scientific Literacy}

\begin{abstract}
This research is aimed at revealing the results of reconstruction, assessment, implementation, and responses of students on the learning material with the context of SSI on additive substance of the foods produced through the implementation of educational reconstruction model. This research was conducted with $R \& D$ method and the design is model of educational recontruction modified. Learning materials with SSI context on food additives content has been developed consist of eight sub chapter. Each sub chapter contains material description, extra reading list and prctices. Assessment of learning materials is done in two ways, validation based on the general criterias and assessment based on Badan Standar Nasional Pendidikan (BSNP) criterias. The resultindicated the learning materials already worthy and qualified for use in science learning process in 8th junior high school. The implementation result shows that learning materials have great influence and improve student's scientific literacy at both competencies and attitude aspects. The student's response suggest that learning materials with SSI context on food additives content already understood and fulfilled students learning expectation.
\end{abstract}

Keywords: learning materials, model of educational reconstruction, socio-scientific issues (SSI), food additives, scientific literacy

How to Cite: Rostikawati, D., \& Permanasari, A. (2016). Rekonstruksi bahan ajar dengan konteks socioscientific issues pada materi zat aditif makanan untuk meningkatkan literasi sains siswa. Jurnal Inovasi Pendidikan IPA, 2(2), 156-164. doi:http://dx.doi.org/10.21831/jipi.v2i2.8814

Permalink/DOI: http://dx.doi.org/10.21831/jipi.v2i2.8814 


\section{Jurnal Inovasi Pendidikan IPA, 2 (2), 2016 - 157}

Diana Ayu Rostikawati, Anna Permanasari

\section{PENDAHULUAN}

Hasil penelitian menunjukkan bahwa kemampuan literasi sains peserta didik Indonesia masih di bawah rata-rata dan secara umum berada pada tahapan terendah, hal tersebut dapat dilihat dari beberapa hasil pengukuran mutu hasil pembelajaran sains peserta didik yang dilakukan secara internasional (Toharudin et al., 2012, p. 16).

Melihat kenyataan tersebut, maka diperlukan inovasi dalam pembelajaran sains. Inovasi-inovasi yang dapat dilakukan antara lain inovasi dalam hal penggunaan strategi pembelajaran, (pendekatan, model maupun metode pembelajaran) seperti yang telah dilakukan oleh Baker, et al. (2009), Khasnabis (2008), Villanueva (2010), inovasi pun telah dilakukan dalam asesmen pembelajaran (Colthorpe, et al., 2015; Fang \& Wei, 2010) dan terakhir dalam bahan ajar (Yusmaita, 2013; Fibonacci \& Sudarmin, 2014).

Inovasi dalam bahan ajar telah dilakukan oleh beberapa peneliti. Menurut Firman (dalam Adisendjaja, 2009, p. 2) bahan-bahan ajar yang ada selama ini lebih menekankan kepada dimensi konten daripada dimensi proses dan konteks, sehingga diduga menyebabkan rendahnya tingkat literasi sains siswa di Indonesia. Oleh karena itu, diperlukan suatu alternatif bahan ajar yang melibatkan aspek-aspek yang mengandung literasi sains yaitu konten, proses dan sikap sains dalam konteks di kehidupan nyata. Berdasarkan hal tersebut, maka diperlukan suatu proses rekonstruksi bahan ajar.

Struktur konten untuk pengajaran tidak dapat diambil langsung dari struktur konten keilmuan, tetapi khusus dibangun kembali dengan memperhatikan tujuan pendidikan serta aspek kognitif dan perspektif afektif siswa.Oleh karenanya, suatu materi konten sains harus diuraikan secara hati-hati kemudian dihubungkan dengan konteks dalam kehidupan nyata (Duit, 2007, p. 6).

Salah satu materi konten sains yang sangat dekat dengan konteks dalam kehidupan nyata adalah materi zat aditif makanan. Penggunaan zat aditif sintesis dalam jumlah sedikit tidak berbahaya. Akan tetapi jika penggunaannya telah melebihi batas aman konsumsi yang diizinkan maka dapat menimbulkan efek samping yang tidak dikehendaki dan merusak makanan itu sendiri, bahkan berbahaya untuk dikonsumsi manusia.
Penggunaan zat aditif yang tidak sewajarnya akhir-akhir ini telah menjadi sorotan masyarakat umum dan muncul sebagai SocioScientific Issues (SSI) kontroversial yang ramai dibicarakan. SSI di definisikan sebagai suatu isu atau masalah yang kompleks dan dapat menimbulkan perdebatan sehingga tidak memiliki jawaban yang definif atau dengan kata lain jawabannya bersifat terbuka (Sadler, 2004, p. 514). Melalui SSI siswa dapat melatih kemampuan argumentasi dan penalaran mereka dalam berbagai sudut pandang. Siswa diberikan kesempatan untuk mengevaluasi, menganalisis dampak dan membuat keputusan mengenai SSI tersebut.

SSI sangat potensial jika digunakan sebagai dasar pembelajaran sains di sekolah. Penggunaan SSI dapat dijadikan penghubung permasalahan nyata di masyarakat dan landasan oleh pebelajar dalam mengeksplorasi konten sains.Dengan SSI yang diterapkan dalam pembelajaran sains diharapkan dapat memberikan pengalaman belajar yang lebih bermakna. Hasil penelusuran menunjukkan bahwa penelitian yang berkaitan dengan penggunaan SSI dalam pembelajaran sains masih terbatas, SSI terkait lingkungan (Zo'bi, 2014) dan isu bioteknologi (Dawson \& Venville, 2009) pernah digunakan untuk mengembangkan keterampilan argumentasi dalam pembelajaran sains, sedangkan pengembangan bahan ajar dengan menggunakan konteks SSI pernah dilakukan pada materi pencemaran lingkungan dan pemanasan global (Nurhayati, 2012).

Masih terbatasnya penggunaan SSI dalam suatu bahan ajar, menunjukkan kurangnya upaya yang optimal terkait pengembangan bahan ajar untuk mengatasi kelemahan-kelemahan dalam bahan ajar yang selama ini digunakan pada pembelajaran sains.

Pernyataan tersebut didukung oleh hasil temuan yang didasarkan pada penelaahan sederhana yang dilakukan terhadap beberapa bahan ajar (khususnya pada materi zat aditif makanan) yang telah ada dan digunakan di kelas VIII sekolah menengah pertama (SMP). Tahapan pembelajaran berbasis SSI yang menjadi acuan memenuhi atau tidak memenuhi tahapantahapan pembelajaran berbasis SSI adalah tahapan pembelajaran berbasis SSI yang dikembangkan melalui Socio Critical and Problem Oriented Lesson Plan(Marks et al., 2014 p.289) yang terdiri atas, (1) pendekatan dan analisis masalah, (2) klarifikasi masalah melalui kegiatan praktikum, (3) melanjutkan isu permasalahan 
sosial, (4) diskusi dan evaluasi, dan (5) metarefleksi.

Berdasarkan hasil penelaahan, diperoleh informasi bahan ajar IPA SMP kelas VIII yang berbentuk buku sekolah elektronik (BSE) belum memenuhi tahapan pembelajaran berbasis SSI atau belum menggunakan SSI sebagai konteks dalam proses pembelajaran. Pernyataan tersebut didasarkan pada hasil persentase terpenuhinya tahapan pembelajaran berbasis SSI pada lima buku ajar yang dianalisis, dua buku memiliki persentase $0 \%$, sedangkan tiga buku lainya memiliki persentase berturut-turut $29,2 \%, 30 \%$, dan $27,3 \%$. Hasil tersebut dijadikan sebagai salah satu alasan bagi penelitian selanjutnya untuk melakukan suatu proses rekonstruksi terhadap bahan ajar yang telah ada sebagai upaya dalam meningkatkan literasi sains siswa.

Rumusan masalah pada penelitian ini adalah "Bagaimanakah rekonstruksi bahan ajar dengan konteks Socio-Scientific Issues (SSI) pada materi zat aditif makanan yang dapat meningkatkan literasi sains siswa?". Tujuan dari penelitian ini adalah untuk mengetahui hasil rekonstruksi, penilaian, implementasi, dan tanggapan siswa terhadap bahan ajar dengan konteks SSI pada materi zat aditif makanan yang dihasilkan melalui penerapan model rekonstruksi pendidikan.

\section{METODE}

Penelitian yang dilakukan ini termasuk penelitian R\&D, yaitu suatu metode penelitian yang digunakan untuk menghasilkan produk tertentu dan menguji keefektifan produk tersebut (Sugiyono, 2014, p. 407). Desain penelitian yang digunakan adalah Model of Educational Reconstruction (MER) yang dimodifikasi. Model rekonstruksi pendidikan ini terdiri atas tiga komponen yang saling bertautan, yaitu: (1) Analisis struktur konten, komponen ini memiliki beberapa proses yakni, analisis literatur, elementarisasi teks dan konstruksi teks. (2) Penelitian pada proses pembelajaran, dan (3) Implementasi dan evaluasi pembelajaran. Jadwal pelaksanaan penelitian disajikan dalam Tabel 1.

\section{Target/Subjek Penelitian}

Subjek penelitian pada penelitian yang akan dilaksanakan ini adalah siswa SMP kelas VIII yang bersekolah di salah satu sekolah kota Bandung dan beberapa guru dengan pengalaman mengajar IPA yang berbeda. Siswa dipilih secara cluster random sampling dan guru dipilih dengan cara purposive sampling (berdasarkan pengalaman mengajar IPA pada interval 5-10 tahun), siswa dan guru yang terpilih akan diberikan kuesioner dengan tujuan untuk mengetahui pre-konsepsi dan perspektif tentang SSI yang berkaitan dengan penggunaan zat aditif makanan.

\section{Prosedur}

Dalam penelitian ini terdapat tiga komponen yang dilaksanakan, komponen-komponen tersebut saling bertautan dan mempengaruhi satu sama lainnya, berikut penjelasannya.

Analisis Struktur Konten dan Penelitian Belajar dan Mengajar

Pada komponen pertama yaitu analisis struktur konten, terdapat tiga proses yakni analisis literatur, elementarisasi teks, dan konstruksi teks. Analisis literatur sangat dipengaruhi oleh penelitian belajar dan mengajar (studi empiris) yang merupakan komponen kedua dalam MER. Dalam studi empiris ini dilakukan telaah prekonsepsi siswa dan perspektif guru terkait konten dan konteks zat aditif makanan melalui kuesioner yang disebarkan pada siswa dan guru.

Hasil dari analisis literatur dan studi empiris yang dilakukan, akan dijadikan acuan untuk perumusan indikator dan tujuan pembelajaran untuk aspek kompetensi dan sikap dalam bahan ajar yang akan direkonstruksi.

Langkah berikutnya adalah elementarisasi teks yang dilakukan melalui pengumpulan bahan dari berbagai sumber, konsep esensial dalam teks asli dari berbagai sumber ini kemudian diidentifikasi dan disusun (penyusunan teks asli), kemudian diperhalus dengan cara dihapus atau disisipi teks lain (analisis wacana).

Selanjutnya, teks hasil analisis wacana selanjutnya dilakukan reduksi didaktik. Reduksi didaktik diperlukan untuk mengurangi tingkat kesulitan materi sehingga diperoleh teks dasar yang lebih mudah dipahami siswa.

Hasil dari reduksi didaktik merupakan teks dasar untuk konten dan konteks zat aditif makanan. Setelah reduksi didaktik, selanjutnya di buat struktur makro yang merupakan lanjutan dari hasil penghalusan dan penyisipan kata berupa analisis proposisi-proposisi yang akan digunakan sebagai dasar pengembangan bahan ajar.

Setelah dilakukan proses elementarisasi teks, kemudian dilakukan konstruksi teks dalam bahan ajar. Konstruksi teks dalam bahan ajar dimulai dengan pembuatan outline bahan ajar yang dalam MER dikenal dengan Outline of 
Principles Formulation of Guidelines. Outline ini berisi urutan penyajian (sequencing) yang berfungsi untuk menentukan urutan dalam mempelajari atau mengajarkannya. Outline dalam bahan ajar ini mengadopsi tahapan pembelajaran berbasis SSI.

Langkah berikutnya yaitu komposit (perpaduan) teks dasar yang dilakukan dengan memperhatikan outline dan tujuan pembelajaran yang telah dibuat. Komposit teks dalam bahan ajar berfungsi untuk menggabungkan konten zat aditif makanan dan konteks SSI yang berkaitan dengan zat aditif makanan. Hasil komposit teks dasar tersebut merupakan teks dalam bahan ajar dengan konteks SSI pada materi zat aditif makanan.

Implementasi Bahan Ajar dalam Pembelajaran dan Evaluasi Hasil Pembelajaran

Pada komponen implementasi dan evaluasi, akan dilaksanakan penelitian dalam dalam suatu pembelajaran di kelas untuk mengetahui pengaruh penggunaan bahan ajar di kelas terhadap peningkatan literasi sains siswa. Tahapan implementasi dilakukan dengan metode weak experiment dengan one-group pretest-posttest design (Fraenkel, Wallen \& Hyun, 2012, p. 269). Skemanya ditunjukkan Tabel 2.
Sebelum dan setelah pembelajaran, siswa diberikan tes (pretest dan posttest) tujuannya untuk mengukur kemampuan literasi sains siswa. Pretest dan posttest yang digunakan untuk mengukur literasi sains berupa soal pilihan ganda. Jumlah soal yang diberikan sebanyak 15 soal. Selanjutnya, akan dianalisis dan dideskripsikan untuk mengetahui apakah penggunaan bahan ajar dengan konteks SSI pada materi zat aditif makanan yang telah dihasilkan memberikan pengaruh atau peningkatan terhadap literasi sains siswa. Selain melakukan penilaian melalui pretest dan posttest, selama proses pembelajaran dilakukan penilaian terhadap aspek sikap dengan menggunakan rubrik penilaian yang telah disiapkan sebelumnya.

Setelah mengimplementasikan bahan ajar, siswa akan diberikan lembar tanggapan untuk mengetahui tanggapan siswa mengenai bahan ajar dengan konteks SSI pada materi zat aditif makanan yang telah dihasilkan melalui MER.

\section{Data, Intrumen, dan Teknik Pengumpulan Data}

Jenis, sumber, dan teknik pengumpulan data yang digunakan dalam penelitian disajikan pada Tabel 3.

Tabel 1. Jadwal Pelaksanaan Penelitian

\begin{tabular}{|c|c|c|c|}
\hline No. & Waktu & Kegiatan & Lokasi \\
\hline 1. & Agustus 2015 & Studi pendahuluan & \\
\hline 2. & September-Desember 2015 & Proses rekonstruksi bahan ajar & \\
\hline 3. & Desember 2015 & $\begin{array}{l}\text { Uji coba soal literasi sains yang terdapat } \\
\text { dalam bahan ajar }\end{array}$ & $\begin{array}{l}\text { Salah satu SMP Negeri di Kota } \\
\text { Bandung }\end{array}$ \\
\hline 4. & Januari 2016 & Penilaian bahan ajar oleh ahli & \\
\hline 5. & Februari 2016 & Implementasi bahan ajar & $\begin{array}{l}\text { Salah satu SMP Negeri di Kota } \\
\text { Bandung }\end{array}$ \\
\hline 6. & Maret-April 2016 & Pengolahan dan analisis data & \\
\hline
\end{tabular}

Tabel 2. Skema One-Group Pretest-Posttest Design

\begin{tabular}{ccc}
\hline Pretest & Treatment & Posttest \\
\hline $\mathrm{T}_{1}$ & $\mathrm{X}$ & $\mathrm{T}_{2}$ \\
\hline
\end{tabular}

Keterangan:

$\mathrm{T}_{1}=$ Pretest dilakukan sebelum diberi perlakuan

$\mathrm{X}=$ Perlakuan diberikan pada siswa melalui penggunaan bahan ajar dengan konteks SSI pada materi zat aditif makanan

$\mathrm{T}_{2}=$ Posttest dilakukan setelah diberi perlakuan 
Jurnal Inovasi Pendidikan IPA, 2 (2), 2016 - 158

Diana Ayu Rostikawati, Anna Permanasari

Tabel 3. Jenis, Sumber, dan Teknik Pengumpulan Data

\begin{tabular}{|c|l|l|l|}
\hline No. & \multicolumn{1}{|c|}{ Jenis Data } & \multicolumn{1}{|c|}{ Sumber Data } & \multicolumn{1}{|c|}{ Teknik Pengumpulan Data } \\
\hline 1. & $\begin{array}{l}\text { Pre-konsepsi siswa dan perspektif guru } \\
\text { tentang materi dan SSI yang berhubungan } \\
\text { dengan zat aditif makanan. }\end{array}$ & $\begin{array}{l}\text { Siswa SMP kelas } \\
\text { VIII } \\
\text { Guru SMP/MTs }\end{array}$ & $\begin{array}{l}\text { Menyebarkan kuesioner pada } \\
\text { siswa } \\
\text { Menyebarkan kuesioner pada } \\
\text { guru }\end{array}$ \\
\hline 2. & $\begin{array}{l}\text { Teks asli, teks dasar, komposit teks dasar, } \\
\text { struktur makro dan } \text { outline bahan ajar. }\end{array}$ & $\begin{array}{l}\text { Buku teks dan } \\
\text { sumber lainnya }\end{array}$ & $\begin{array}{l}\text { Analisis struktur konten } \\
\text { (elementarisasi dan konstruksi } \\
\text { teks) }\end{array}$ \\
\hline 3. & Hasil penilaian bahan ajar & $\begin{array}{l}\text { Dosen dengan } \\
\text { beberapa kriteria } \\
\text { Guru SMP/MTs }\end{array}$ & $\begin{array}{l}\text { Validasi bahan ajar berdasarkan } \\
\text { kriteria umum } \\
\text { Penilaian bahan ajar berdasarkan } \\
\text { kriteria BSNP }\end{array}$ \\
\hline 4. & Hasil pretest dan posttest & Siswa SMP kelas VIII & Pretest dan Posttest \\
\hline 5. & $\begin{array}{l}\text { Hasil penilaian literasi sains pada aspek sikap } \\
\text { terhadap bahan ajar }\end{array}$ & Siswa SMP kelas VIII & $\begin{array}{l}\text { Rubrik penilaian literasi sains } \\
\text { pada aspek sikap }\end{array}$ \\
\hline 6. & Hasil tanggapan siswa terhadap bahan ajar & Siswa SMP kelas VIII & Lembar tanggapan siswa \\
\hline
\end{tabular}

\section{Teknik Analisis Data}

Analisis data yang akan dilakukan setelah memperoleh data dalam penelitian ini diantaranya:

\section{Analisis Kuesioner Siswa dan Guru}

Hasil kuesioner yang diberikan pada siswa dan guru akan diolah menggunakan metode kualitatif sehingga akan dikumpulkan dan dibahas secara deskriptif.

Validasi dan Penilaian Bahan Ajar

\section{Validasi Berdasarkan Kriteria Umum}

Bahan ajar yang telah disusun akan divalidasi berdasarkan kriteria kesesuaian antara tujuan pembelajaran dengan indikator dan aspek PISA 2012, kesesuaian antara bahan ajar dengan tujuan pembelajaran, kesesuaian antara urutan pembelajaran dalam bahan ajar dengan tahapan pembelajaran SSI, terpenuhinya keluasan pendahuluan dalam bahan ajar, terpenuhinya soal evaluasi dalam bahan ajar untuk menilai kemampuan literasi sains, dan tercakupnya materi yang diuraikan dalam bahan ajar pada abstraksi (rangkuman) di akhir bahan ajar. Data hasil validasi diolah dengan menggunakan metode Content Validity Ratio (CVR) dan Content Validity Index (CVI).

\section{Penilaian Berdasarkan Kriteria Badan Standar Nasional Pendidikan (BSNP)}

Konteks penilaian didasarkan pada beberapa aspek diantaranya, kelayakan isi, kelayakan penyajian, kebahasaan, dan kegrafikan.
Analisis Hasil Uji Coba Instrumen Tes Literasi Sains

Uji validitas, reliabilitas, daya pembeda, dan indeks kesukaran dilakukan terhadap instrumen tes literasi sains yang telah disusun sehingga instrumen layak digunakan dalam penelitian.

Analisis Hasil Tes Literasi Sains Aspek Kompetensi pada Materi Zat Aditif Makanan

Untuk menganalisis hasil tes kemampuan literasi sains aspek kompetensi pada materi zat aditif makanan dilakukan dengan langkahlangkah sebagai berikut: (a) Penskoran pretest dan posttest. (b) Uji Statistik Inferensial, yaitu Pengujian ini dilakukan dengan bantuan program SPSS Versi 22. (c) Perhitungan gain ternormalisasi (n-gain).

Analisis deskriptif dilakukan untuk menilai literasi sains aspek sikap dan tanggapan siswa terhadap bahan ajar dengan konteks SSI pada materi zat aditif makanan.

\section{HASIL DAN PEMBAHASAN}

\section{Hasil Bahan Ajar dengan Konteks SSI pada Materi Zat Aditif Makanan}

Setelah melewati proses analisis struktur konten yang melibatkan analisis literatur, elementarisasi teks dan konstruksi teks serta mempertimbangkan hasil studi empiris terhadap pre-konsepsi siswa dan perspektif guru, maka dihasilkan suatu bahan ajar dengan konteks SSI pada materi zat aditif makanan. Bahan ajar yang dikembangkan ini terdiri atas delapan sub bab, yaitu zat pengawet makanan, zat pewarna makanan, zat penyedap rasa, aroma, dan pe- 
nguat rasa makanan, zat pemanis makanan, zat aditif makanan lainnya, pengaruh zat aditif berbahaya pada kesehatan, zat alternatif pengganti zat aditif berbahaya pada makanan, dan membaca informasi pada kemasan makanan. Setiap sub bab memuat deskripsi materi, daftar bacaan tambahan yaitu dan soal latihan. Daftar bacaan tambahan yang dimaksudkan dalam bahan ajar adalah bagian-bagian yang terkait seperti pengetahuan tambahan atau informasi yang akan menunjang wawasan siswa terhadap materi zat aditif makanan.

Ciri khas dari bahan ajar yang dihasilkan ini adalah dengan dimasukkannya konteks SSI dalam bahan ajar. Urutan bahan ajar (Outline) disesuaikan dengan tahapan pembelajaran SSI. Berikut tampilan tahapan pembelajaran SSI dalam bahan ajar.

\section{Pendekatan dan Analisis Masalah}

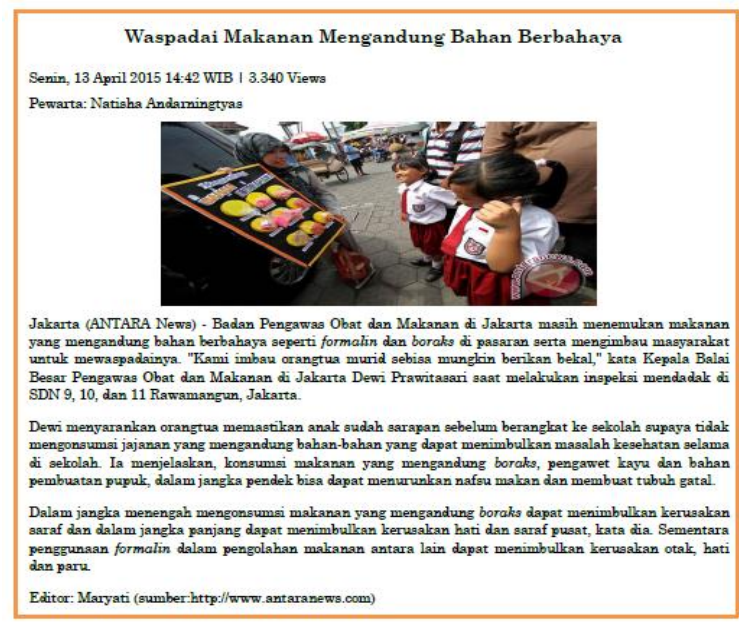

Gambar 1. Tampilan Tahapan Pendekatan dan Analisis Masalah dalam Bahan Ajar

\section{Klarifikasi Masalah Melalui Kegiatan Praktikum}

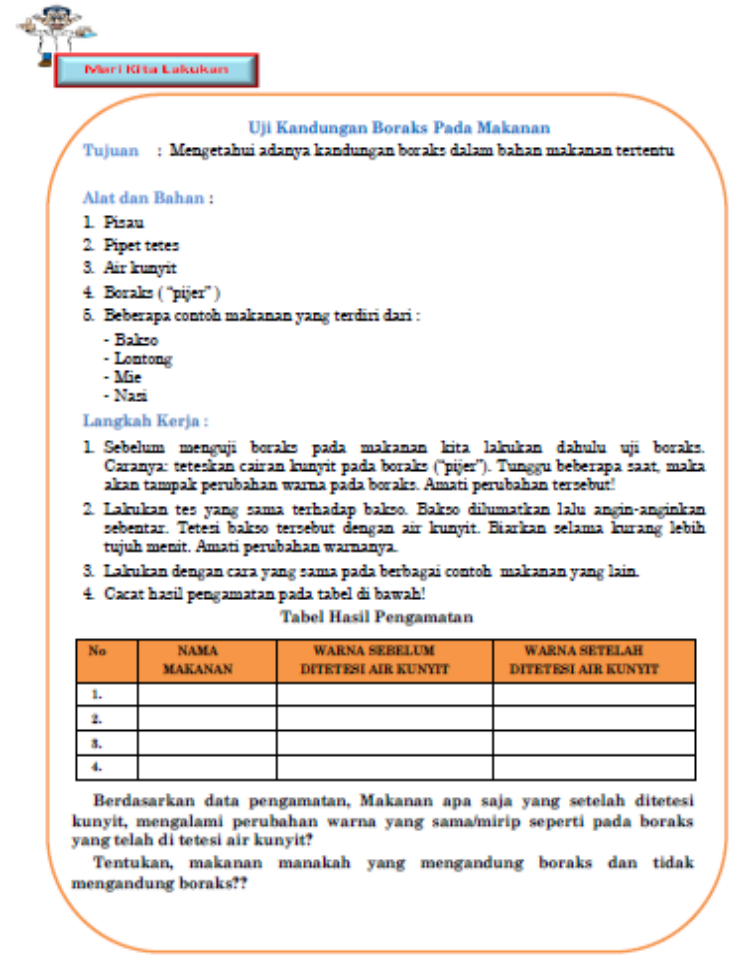

Gambar 2. Tampilan Tahapan Klarifikasi Masalah Melalui Kegiatan Praktikum dalam Bahan Ajar

\section{Melanjutkan Isu Permasalahan Sosial}

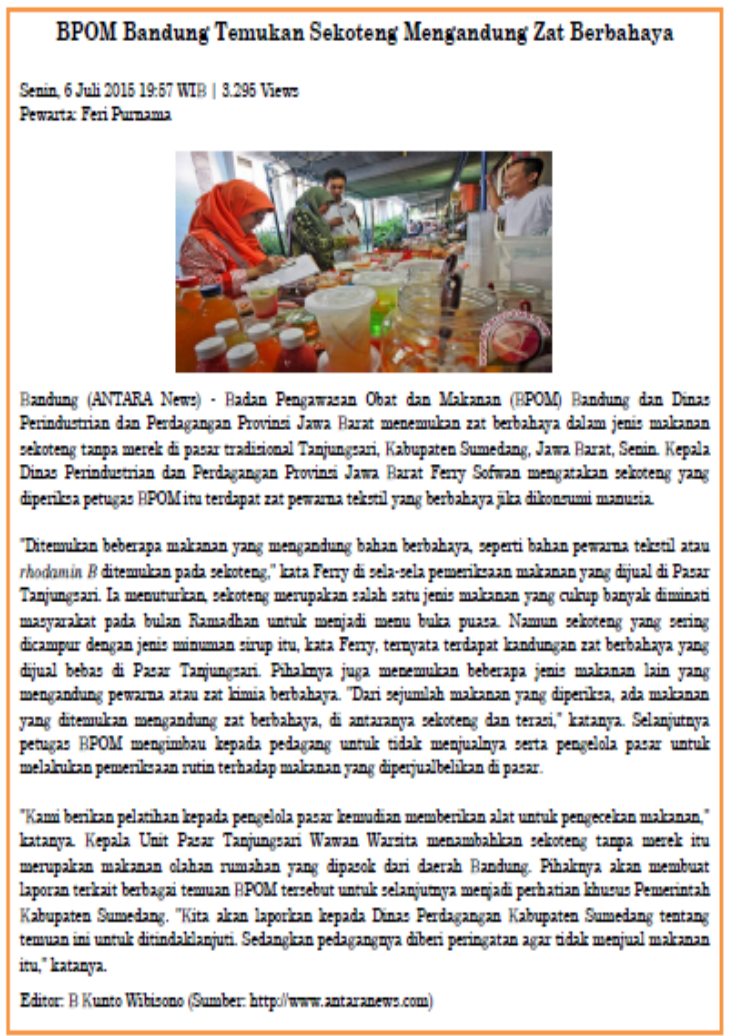

Gambar 3. Tampilan Tahapan Melanjutkan Isu Permasalahan Sosial dalam Bahan Ajar 


\section{Jurnal Inovasi Pendidikan IPA, 2 (2), 2016 - 159}

Diana Ayu Rostikawati, Anna Permanasari

\section{Diskusi dan Evaluasi}

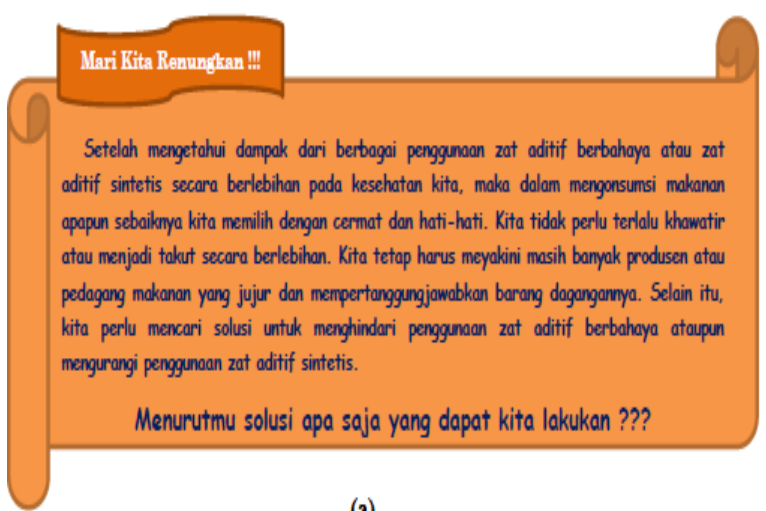

(a)

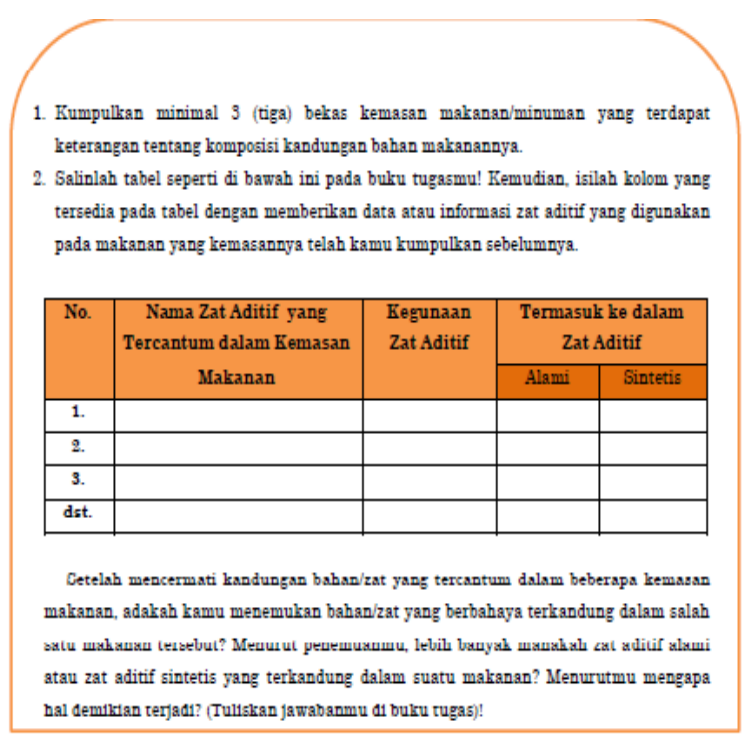

(b)

Gambar 4. Tampilan Tahapan Diskusi dan Evaluasi dalam Bahan Ajar

\section{Metarefleksi}

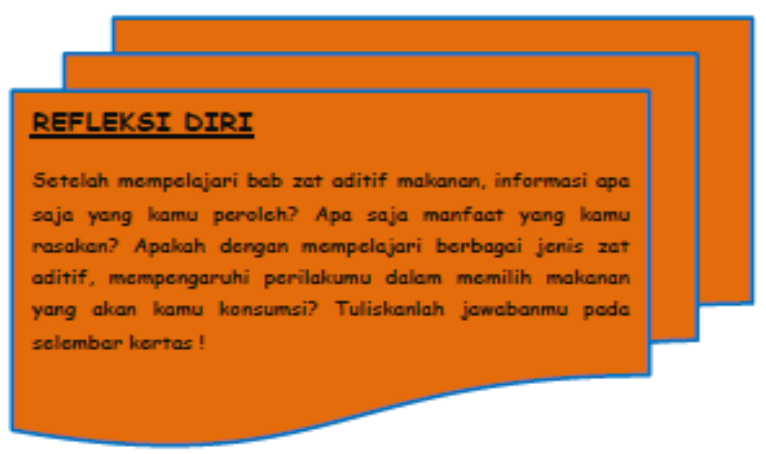

Gambar 5. Tampilan Tahapan Metarefleksi dalam Bahan Ajar

Selain menggunakan tahapan pembelajaran dan konteks SSI, bahan ajar diperkaya dengan daftar bacaan tambahan ditujukan untuk menarik minat siswa agar termotivasi untuk mempelajari materi zat aditif makanan. Daftar bacaan tambahan yang dimaksud adalah sebagai berikut.

\section{Kolom "Tahukah Kamu?"}

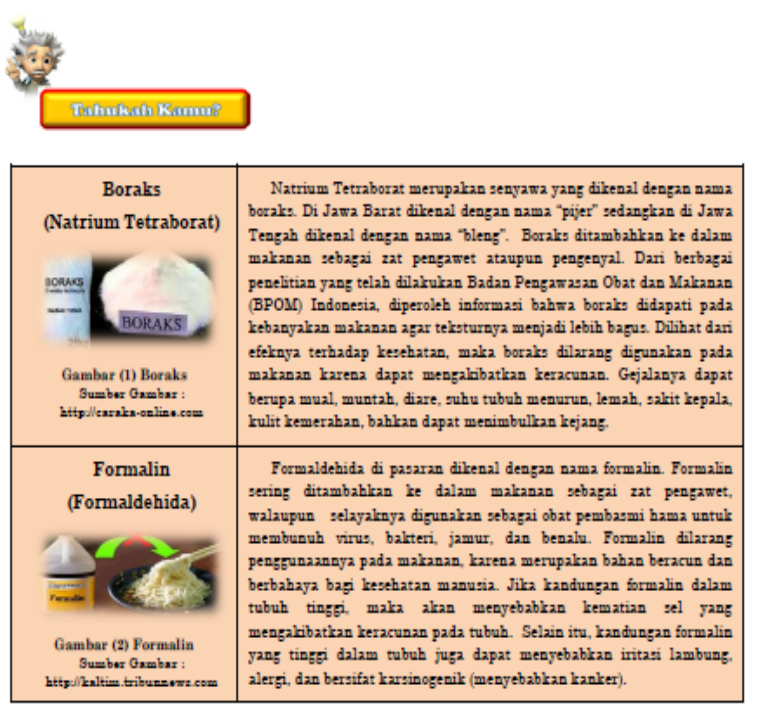

Gambar 6. Tampilan Kolom "Tahukah Kamu?"

Kolom "Info Sains" dan "Untuk Diingat !!!"
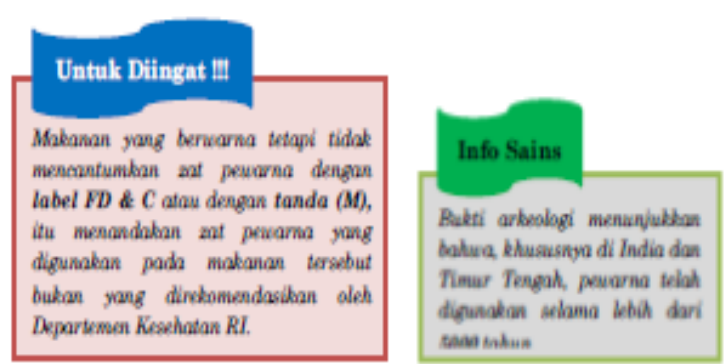

Gambar 7. Tampilan Kolom "Info Sains" dan "Untuk Diingat !!!"

\section{Kolom "Internet Explore"}

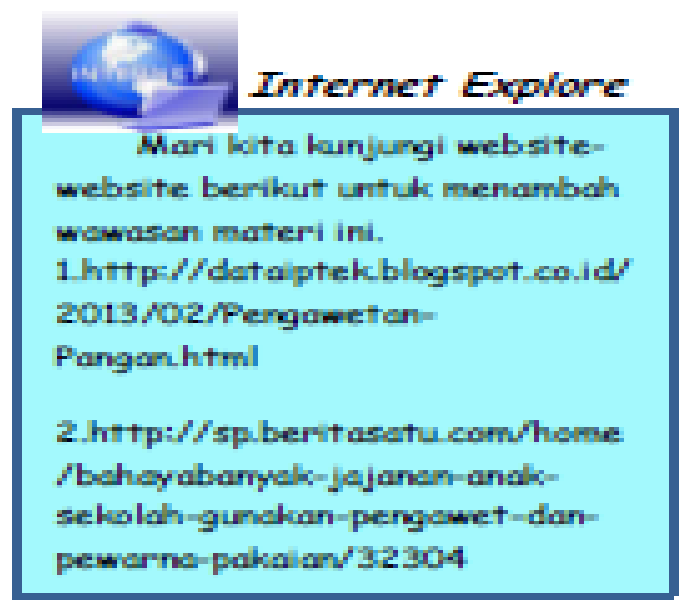

Gambar 8. Tampilan Kolom"Internet Explore" 


\section{Kolom "Mari Kita Renungkan"}

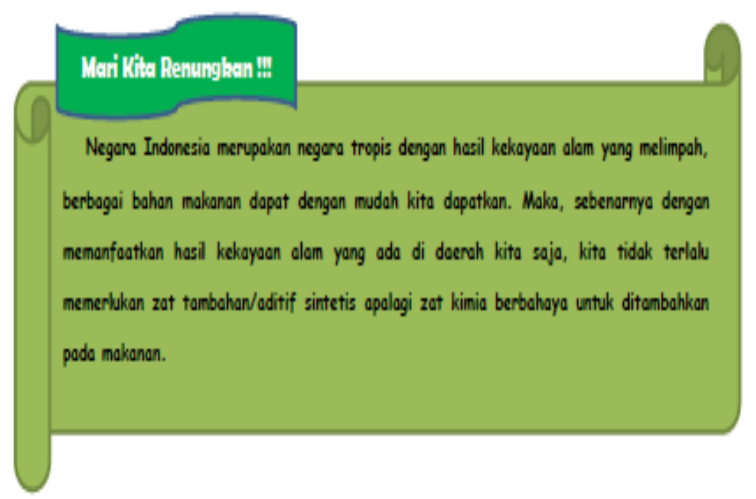

Gambar 9. Tampilan Kolom "Mari Kita Renungkan"

\section{Hasil Penilaian para Ahli terhadap Bahan Ajar dengan Konteks SSI pada Materi Zat Aditif Makanan}

Penilaian ahli terhadap bahan ajar dengan konteks SSI pada materi zat aditif makanan untuk meningkatkan literasi sains siswa kelas VIII SMP dilakukan dengan 2 cara, yaitu validasi berdasarkan kriteria umum dan penilaian berdasarkan kriteria Badan Standar Nasional Pendidikan (BSNP).

Validasi Bahan Ajar Berdasarkan Kriteria Umum

Hasil validasi bahan ajar berdasarkan kriteria umum disajikan pada tabel 4 berikut.

Tabel 4. Hasil Validasi Bahan Ajar Berdasarkan Kriteria Umum

\begin{tabular}{lcc}
\hline \multicolumn{1}{c}{ Kriteria } & CVR & CVI \\
\hline $\begin{array}{l}\text { Kesesuaian antara tujuan } \\
\text { pembelajaran dengan indikator dan }\end{array}$ & 1,00 & 0,93 \\
$\begin{array}{l}\text { aspek PISA } 2012 \text { (Kompetensi dan } \\
\text { Sikap) }\end{array}$ & & \\
$\begin{array}{l}\text { Kesesuaian antara bahan ajar dengan } \\
\text { tujuan pembelajaran }\end{array}$ & 1,00 \\
$\begin{array}{l}\text { Kesesuaian antara urutan } \\
\text { pembelajaran dalam bahan ajar } \\
\text { dengan tahapan pembelajaran Socio- }\end{array}$ & 0,60 \\
$\begin{array}{l}\text { Scientific Issues } \\
\text { Terpenuhinya keluasan pendahuluan } \\
\text { dalam bahan ajar }\end{array}$ & 1,00 \\
$\begin{array}{l}\text { Terpenuhinya soal evaluasi dalam } \\
\text { bahan ajar untuk menilai kemampuan } \\
\text { literasi sains }\end{array}$ & \\
$\begin{array}{l}\text { Abstraksi (rangkuman) di akhir bahan } \\
\text { ajar sudah mencakup materi yang } \\
\text { diuraikan dalam bahan ajar }\end{array}$ & \\
\hline \multicolumn{1}{c}{ Berdasarkan hasil validasi yang telah di- } \\
lakukan oleh validator yang terdiri atas lima
\end{tabular}

dosen ahli dan lima guru bidang IPA, diperoleh kategori untuk setiap kriteria adalah valid. Hal tersebut dikarenakan $\mathrm{CVR}_{\text {hitung }}>\mathrm{CVR}_{\text {tabel, }}$ dengan jumlah validator sebanyak sepuluh orang maka nilai $\mathrm{CVR}_{\text {tabel }}$ yang menjadi rujukan adalah0,52. Berdasarkan hasil yang ditunjukkan tabel diatas, nilai $\mathrm{CVR}_{\text {hitungyang diperoleh untuk }}$ setiap kriteria lebih besar dibandingkan dengan nilai $\mathrm{CVR}_{\text {tabel. }}$.

Perolehan nilai CVI menunjukkan bahwa bahan ajar yang telah divalidasi layak digunakan dalam proses pembelajaran IPA di kelas VIII SMP.

\section{Penilaian Bahan Ajar Berdasarkan Kriteria BSNP}

Bagian kedua merupakan penilaian bahan ajar berdasarkan kriteria BSNP, kriteria ini terdiri atas kelayakan isi, kelayakan penyajian, kebahasaan dan kegrafikan. Hasil penilaian bahan ajar berkonteks SSI pada materi zat aditif makanan untuk meningkatkan literasi sains siswa, disajikan pada Gambar 10.

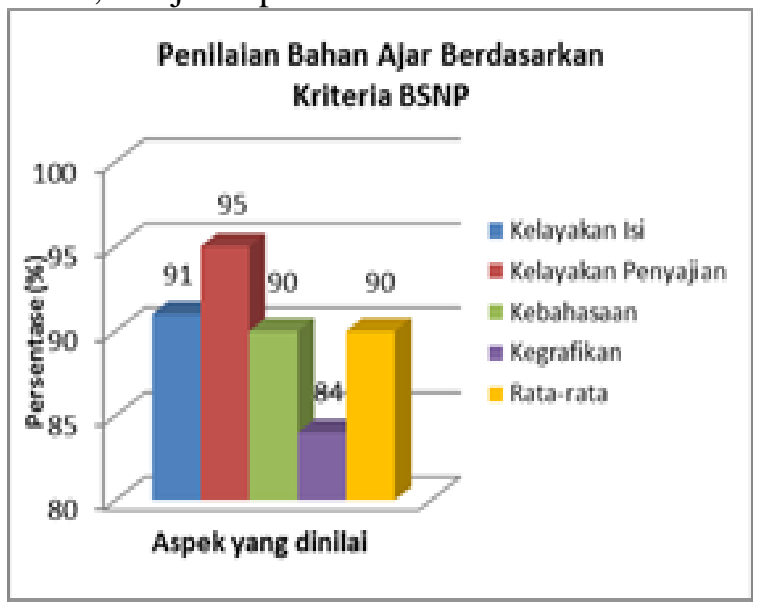

Gambar 10. Diagram Hasil Penilaian Bahan Ajar Berdasarkan Kriteria BSNP

Berdasarkan Gambar 10 perolehan persentase skor untuk setiap aspek yaitu kelayakan isi, kelayakan penyajian, kebahasaan dan kegrafikan, diperoleh informasi bahwa secara keseluruhan bahan ajar berkonteks SSI pada materi zat aditif makanan sudah sangat sesuai dan memenuhi syarat bahan ajar menurut BSNP sehingga dapat dijadikan bahan pedoman dalam proses pembelajaran IPA di kelas VIII SMP. 


\section{Hasil Implementasi Bahan Ajar dengan Konteks SSI pada Materi Zat Aditif Makanan}

Literasi Sains Siswa pada Aspek Kompetensi

Tabel 5. Hasil Perhitungan Uji Normalitas Pretest dan Posttest

\begin{tabular}{ccccc}
\hline Sumber & \multicolumn{4}{c}{ Shapiro-Wilk } \\
\cline { 2 - 5 } Data & Statistik & Df & Sig. & Distribusi \\
\hline Pretest & 0,967 & 35 & 0,362 & Normal \\
Posttest & 0,927 & 35 & 0,022 & $\begin{array}{c}\text { Tidak } \\
\text { normal }\end{array}$ \\
\hline
\end{tabular}

Berdasarkan hasil perhitungan uji normalitas data pretest dan posttest menggunakan SPSS versi 22 diperoleh data taraf signifikansi $(\alpha)<0,05$ pada data posttest, hal ini menunjukkan data tidak berdistribusi normal. Hasil uji normalitas dijadikan acuan untuk uji selanjutnya yaitu uji hipotesis, karena data tidak berdistribusi nomal maka uji statistik yang digunakan adalah statistik non parametrik tes, yaitu Uji Peringkat-Bertanda Wilcoxon(Wilcoxon Signed Ranks Test) yang hasilnya disajikan dalam Tabel 6.

Tabel 6. Hasil Perhitungan Uji PeringkatBertanda Wilcoxon

\begin{tabular}{|c|c|c|c|}
\hline $\begin{array}{c}\text { Sumber } \\
\text { Data }\end{array}$ & $\begin{array}{c}\text { Wilcoxon } \\
\text { Signed } \\
\text { Ranks Test }\end{array}$ & $\begin{array}{l}\text { Asym. } \\
\text { Sig. (2- } \\
\text { tailed) }\end{array}$ & Keterangan \\
\hline $\begin{array}{l}\text { Pretest } \\
\text { dan } \\
\text { Posttest }\end{array}$ & $-5,027$ & 0,000 & $\mathrm{H}_{0}$ ditolak \\
\hline
\end{tabular}

Peringkat-Bertanda Wilcoxon untuk data pretest dan posttest menggunakan SPSS versi 22 diperoleh taraf signifikansi $(\alpha)<0,05$ pada data, sehingga dapat disimpulkan bahwa $\mathrm{H}_{0}$ ditolak. Dengan demikian dapat dikatakan terdapat peningkatan yang signifikan terhadap literasi sains siswa setelah bahan ajar diimplementasikan.

Untuk mengetahui seberapa besar peningkatan tersebut maka dilakukan perhitungan skor gain ternormalisasi. Hasil perhitungan skor gain ternormalisasi yang diperoleh berdasarkan data pretest dan posttest disajikan pada Tabel 7.

Tabel 7. Hasil Perhitungan Skor Gain Ternormalisasi

\begin{tabular}{cccc}
\hline Skor $<g>$ & Kategori & $\begin{array}{c}\text { Jumlah } \\
\text { Siswa }\end{array}$ & Persentase \\
\hline$<g>\geq 0,70$ & Tinggi & 11 & $30,6 \%$ \\
\hline $0,30 \leq<g><0,70$ & Sedang & 16 & $44,4 \%$ \\
\hline$<g><0,30$ & Rendah & 9 & $25,0 \%$ \\
\hline
\end{tabular}

Berdasarkan Tabel 7, jumlah siswa yang memperoleh skor gain sedang memiliki persentase tertinggi sebesar 44,4\% (11 siswa), kemudian skor gain tinggi sebesar 30,6\% (16 siswa), dan terakhir adalah skor gain rendah sebesar 25,0\% (9 siswa).

\section{Literasi Sains Siswa pada Aspek Sikap}

Selain dilakukan penilaian terhadap kemampuan literasi sains siswa pada aspek kompetensi, dilakukan pula penilaian terhadap kemampuan literasi sains siswa pada aspek sikap. Perhitungan ini didasarkan pada rubrik penilaian yang telah dipersiapkan sebelumnya. Hasil perhitungan kemampuan literasi sains siswa pada aspek sikap disajikan pada Tabel 8 .

Tabel 8. Hasil Perhitungan Kemampuan Literasi Sains pada Aspek Sikap

\begin{tabular}{cccc}
\hline Nilai & Kriteria & $\begin{array}{c}\text { Jumlah } \\
\text { Siswa }\end{array}$ & $\begin{array}{c}\text { Persentase } \\
(\%)\end{array}$ \\
\hline $80-$ & Sangat & 17 & 47,2 \\
100 & Baik & 5 & 14,0 \\
$70-79$ & Baik & 7 & 19,4 \\
$60-69$ & Cukup & 7 & 19,4 \\
$<60$ & Kurang & \multicolumn{3}{c}{ Berdasarkan Tabel 8, jumlah siswa yang }
\end{tabular}
masuk ke dalam kriteria "sangat baik" memiliki persentase tertinggi sebesar 47,2\% (17 siswa), diikuti oleh jumlah siswa yang masuk kedalam kriteria "cukup" dan "kurang" yang memiliki persentase yang sama yakni sebesar 19,4\% (7 siswa), dan terakhir adalah jumlah siswa yang masuk kedalam kriteria "baik" yang memiliki persentase sebesar 14,0\% (5 siswa).

Hasil perhitungan nilai rata-rata kemampuan literasi sains siswa pada aspek sikap untuk seluruh siswa adalah sebesar 76,2 yang artinya berada pada kriteria "baik". Secara keseluruhan diperoleh informasi bahwa penggunaan bahan ajar dengan konteks SSI pada materi zat aditif makanan dapat meningkatkan kemampuan literasi sains siswa pada aspek kompetensi secara signifikan. Hasil ini diperkuat dengan perolehan nilai skor gain ternormalisasi yang didapatkan.

Selain hasil penilaian terhadap kemampuan literasi sains pada aspek kompetensi yang menunjukkan hasil yang "baik", hasil penilaian terhadap literasi sains pada aspek sikap pun menunjukkan hasil yang serupa, hal tersebut ditunjukkan oleh persentase terbesar yang didapatkan oleh kriteria "Sangat Baik".

Berdasarkan hal tersebut dapat dikatakan bahan ajar dengan konteks SSI pada materi zat aditif makanan yang dikembangkan melalui 
proses model rekonstruksi pendidikan memiliki pengaruh yang besar dan dapat meningkatkan literasi sains siswa. Pengaruh yang besar terhadap literasi sains siswa disebabkan proses rekonstruksi yang dilakukan mempertimbangkan tujuan pendidikan dan aspek kognitif serta afektif siswa, sehingga materi pelajaran dapat lebih mudah dipahami oleh siswa. Faktor yang menyebabkan bahan ajar mudah dipahami oleh siswa adalah penggunaan SSI sebagai konteks dan tahapan pembelajaran dalam bahan ajar. Isu-isu yang disajikan dalam bahan ajar, merupakan isu-isu yang ada di sekitar siswa dan sangat berkaitan dengan konteks dalam kehidupan nyata sehingga memotivasi siswa untuk memaknai materi pelajaran yang sedang dipelajarinya.

Pernyataan tersebut didukung oleh penemuan Zo'bi (2012, p. 121) yang menyatakan bahwa pembelajaran dengan menggunakan SSI akan meningkatkan kemampuan siswa dalam membuat keputusan terkait isu sosial yang kontroversial, hal tersebut dikarenakan pembelajaran dengan menggunakan SSI bertujuan untuk melibatkan siswa dalam proses membuat keputusan, menunjukkan pada siswa pentingnya keputusan mereka dan melatih mereka untuk mempelajari suatu masalah secara komprehensif, termasuk masalah yang berhubungan dengan moral mereka.

Hal tersebut diperkuat oleh hasil penelitian yang dilakukan oleh Fowler, Zeidler, dan Sadler (dalam Zeidler \& Nichols, 2009, p.54) yang menyatakan bahwa pembelajaran dengan menggunakankonteks SSI dapat meningkatkan sensitivitas moral siswa, sehingga memberikan kontribusi bagi perkembangan moral siswa secara keseluruhan. Menurut mereka, melalui pembelajaran dengan konteks SSI siswa diarahkan untuk menggali dan memperhatikan kehidupan, kesehatan dan kesejahteraan orang lain.

Hasil penelitian ini menunjukkan penggunaan bahan ajar berkonteks SSI ini memiliki pengaruh dan terbukti dapat meningkatkan literasi sains siswa. Menurut PISA literasi sains dapat didefinisikan sebagai kemampuan menggunakan pengetahuan sains, mengidentifikasi pertanyaan, dan menarik kesimpulan terhadap bukti-bukti, dalam rangka memahami serta membuat keputusan berkenaan dengan alam dan perubahan yang dilakukan terhadap alam melalui aktivitas manusia. PISA memandang pendidikan sains berfungsi untuk mempersiapkan warga negara masa depan, yakni warna negara yang mampu berpartisipasi dalam masyarakat yang semakin terpengaruh oleh kemajuan sains dan teknologi (OECD, 2013, p. 100).

Peningkatan literasi sains sebagai dampak penggunaan konteks SSI juga didukung oleh Pinzino (2012) yang menyatakan pembelajaran berbasis SSI dapat meningkatkan literasi sains dan dapat membantu siswa menjadi warga negara yang bertanggung jawab, disebabkan pembelajaran berbasis SSI mempersiapkan siswa untuk mengkaji dan meneliti masalah sosial yang berhubungan dengan sains.

Hal senada yang berkaitan dengan penggunaan SSI untuk meningkatkan literasi sains siswa diberikan oleh Sadler (dalam Nuangchalerm, 2012, p.36) yang menyatakan SSI adalah implikasi dari moral dan etika, oleh karena itu promosi dari literasi sains memerlukan pembelajaran berbasis SSI. SSI memberikan cara untuk mengeksplorasi NOS, menjembatani antara siswa dan literasi sains, menghubungkan antara sains dan masyarakat, serta mendemokrisasi sains dalam masyarakat.

Peningkatan literasi sains siswa yang cukup baik sangat berhubungan dan berbanding lurus dengan tanggapan siswa terhadap kualitas bahan ajar yang dihasilkan.

Tanggapan siswa terhadap bahan ajar yang dihasilkan dengan menggunakan model rekonstruksi pendidikan (MER) dianalisis berdasarkan tanggapan siswa pada setiap item pernyataan yang diberikan. Hasil tanggapan siswa terhadap bahan ajar dapat dilihat pada Tabel 9.

Tabel 9. Hasil Perhitungan Persentase Tanggapan Siswa Terhadap Bahan Ajar

\begin{tabular}{ccccc}
\hline & \multicolumn{4}{c}{ Persentase Tanggapan (\%) } \\
\cline { 2 - 5 } No. & $\begin{array}{c}\text { Sangat } \\
\text { Tidak } \\
\text { Setuju } \\
\text { (STS) }\end{array}$ & $\begin{array}{c}\text { Tidak } \\
\text { Setuju } \\
\text { (TS) }\end{array}$ & $\begin{array}{c}\text { Setuju } \\
\text { (S) }\end{array}$ & $\begin{array}{c}\text { Sangat } \\
\text { Setuju } \\
\text { (SS) }\end{array}$ \\
\hline 1 & 0 & 0 & 47,2 & 52,8 \\
2 & 0 & 2,8 & 63,9 & 33,3 \\
3 & 0 & 0 & 66,7 & 33,3 \\
4 & 0 & 0 & 77,8 & 22,2 \\
5 & 0 & 8,3 & 52,8 & 38,9 \\
6 & 0 & 11,1 & 55,6 & 33,3 \\
7 & 0 & 8,3 & 66,7 & 25,0 \\
8 & 0 & 2,8 & 80,5 & 16,7 \\
9 & 0 & 5,5 & 52,8 & 41,7 \\
10 & 2,8 & 2,8 & 50 & 44,4 \\
11 & 0 & 8,3 & 33,3 & 58,3 \\
\hline
\end{tabular}

Untuk mengetahui kategori akumulasi jumlah skor tanggapan siswa yang terdiri atas 11 item pernyataan mengenai kualitas bahan ajar dengan konteks SSI pada materi zat aditif 
makanan, dalam bentuk garis kontinum sebagai berikut:

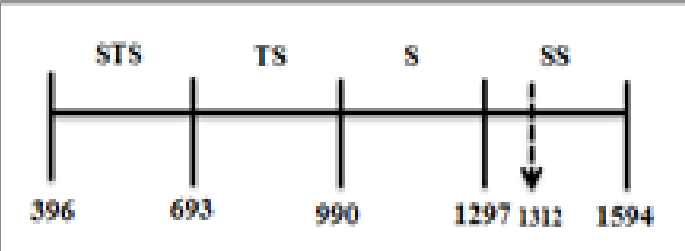

Gambar 11. Garis Kontinum untuk Kualitas Bahan Ajar dengan konteks SSI pada Materi Zat Aditif Makanan

Jumlah skor tanggapan siswa pada 11 item pernyataan pada variabel kualitas bahan ajar yang dihasilkan dari seluruh pernyataan hasil skor adalah 1312. Jumlah tersebut terletak pada garis 1297 dan 1594 dan dalam kategori sangat setuju. Maka dapat dikatakan sebagian besar siswa memberikan respon positif terhadap bahan ajar dan menyatakan bahan ajar dengan konteks SSI pada materi zat aditif makanan sudah dipahami dan memenuhi harapan belajar siswa.

\section{SIMPULAN DAN SARAN}

\section{Simpulan}

Berdasarkan hasil penelitian, diperoleh beberapa informasi diantaranya bahan ajar yang dihasilkan ini terdiri atas delapan sub bab. Setiap sub bab memuat deskripsi materi, daftar bacaan tambahan dan soal latihan. Ciri khas dari bahan ajar yang dihasilkan ini adalah dengan dimasukkannya konteks SSI dalam bahan ajar.Urutan bahan ajar (Outline) disesuaikan dengan tahapan pembelajaran SSI.

Penilaian bahan ajar dilakukan dengan 2 cara, yaitu validasi berdasarkan kriteria umum dan penilaian berdasarkan kriteria Badan Standar Nasional Pendidikan (BSNP). Hasil penilaian menunjukkan bahan ajar sudah layak dan memenuhi syarat untuk digunakan dalam proses pembelajaran IPA di kelas VIII SMP.

Hasil implementasi bahan ajar menunjukkan bahwa bahan ajar memiliki pengaruh yang besar dan dapat meningkatkan literasi sains siswa baik pada aspek kompetensi maupun sikap.Hasil tanggapan siswa terhadap kualitas bahan ajar menunjukkan bahan ajar dengan konteks SSI pada materi zat aditif makanan sudah dipahami dan memenuhi harapan belajar siswa.

\section{Saran}

Proses rekonstruksi bahan ajar dengan konteks SSI perlu dikembangkan untuk materimateri IPA lainnya, hal ini dikarenakan masih banyak sekali materi IPA yang berkaitan dengan isu-isu sosial dalam masyarakat dan kehidupan sehari-hari.

\section{DAFTAR PUSTAKA}

Adisendjaja, Y. H. (2009). Analisis buku ajar biologi SMA kelas $X$ di kota Bandung berdasarkan literasi sains. Bandung: FPMIPA-Universitas Pendidikan Indonesia. Retrieved fromhttp://file.upi.edu

Baker. D.R.,et al. (2009). The communication in science inquiry project (CISIP): a project to enhance scientific literacy through the creation of science classroom discourse communities: International Journal of Environmental \& Science Education, 4(3), 259-274.Retrieved fromhttp://files.eric.ed.gov/fulltext/EJ884 396.pdf

Colthorpe, K., et.al. (2015). Progressive development of scientific literacy through assessment in inquiry-based biomedical science curricula. International Journal of Innovation in Science and Mathematics Education, 23(5), 52-64. Retrieved fromhttp://openjournals.library.usyd.edu. au

Dawson, V., \& Venville, G.J. (2009). Highschool student's informal reasoning and argumentation about biotechnology: an indicator of scientific literacy?. International Journal of Science Education, 31(11), Abstract. Retrieved fromhttp://www.tandfonline.com/doi/abs/

Duit, R. (2007). Science education research internationally. Conceptions, research methods, domains of research. Eurasia Journal of Mathematics, Science \& Technology Education, 3(1), 3-15. Retrieved fromhttp://www.ejmste.org/v3n1/EJMST Ev3n1_Duit.pdf

Fang, Z., \& Wei, Y. (2010). Improving middle school students' science literacy through reading infusion. The Journal of Educational Research, 103(1), 262-273. Retrieved 
fromhttp://files.eric.ed.gov/fulltext/EJEJ8 79927

Fibonacci, A., \& Sudarmin. (2014). Development fun-chem learning materials integrated socio-science issues to increase students scientific literacy. International Journal of Science and Research, 3(11), 708-713. Retrieved fromhttp://www.ijsr.net/archive/v3i11/T0 NUMTQxMDMz.pdf

Fraenkel, J.R., Wallen, N.E., \& Hyun, H.H. (2012). How to design and evaluate research in education. 8th Edition. Boston: McGraw Hill.

Khasnabis, D. (2008). Developing scientific literacy through classroom instruction: investigating learning opportunities across three modes of inquiry-based science instruction. Dissertations, University of Michigan.Retrieved fromhttp://deepblue.lib.umich.edu/

Marks, R., et al. (2014). The societal dimension in german science education-from tradition toward selected cases and recent developments. Eurasia Journal of Mathematics, Science, \& Technology Education, 10(4), 285-296. Retrieved fromhttp://www.ejmste.com/

Nuangchalerm, P. (2010). Engaging students to perceive nature of science through socioscientificissues-based

instruction.European Journal of Social Science,13(1),34-37.Retrieved from http://files.eric.ed.gov/fulltext/ED508531. pdf

Nurhayati, H. M. (2014). Pengembangan bahan ajar berkonteks socio scientific issues (SSI) untuk mengeksplisitkan hakikat sains (NOS) dan berpikir kritis pada materi pencemaran lingkungan dan pemanasan global. Abstrak, Universitas Negeri Malang.Retrieved fromhttp://library.um.ac.id/freecontents/index.php/

OECD. (2013). PISA 2012 assessment and analytical framework. Retrieved fromhttp://www.oecd.org/pisa.

Pinzino, D.W. (2012). Socioscientific issues: apath towards advanced scientific literacy and improved conceptual understanding of socially controversial scientific theories. Dissertations, University of South Florida.Retrieved fromhttp://scholarcommons.usf.edu/cgi/vi ewcontent.cgi

Sadler, T.D (2004). Informal reasoning regarding socioscientific issues: a critical review of research. Journal of Research in Science Teaching,41(1), 513-536. Retrieved

fromhttp://files.eric.ed.gov/fulltext/EJ106 8658.pdf

Sugiyono. (2014). Metode penelitian pendidikankuantitatif, kualitatif dan $R \& D$. Cetakan ke-19. Bandung: Alfabeta.

Toharudin, U., Hendrawati, S., Rustaman, A. (2011). Membangun literasi sains peserta didik. Cetakan pertama. Bandung: Humaniora.

Villanueva, M.G. (2010). Integrated teaching strategies model for improved scientific literacy in second language learners. Dissertations, Nelson Mandela Metropolitan University.Retrieved fromhttp://www.nmmu.ac.za/helpingteac hers/GroupProjectWebb/

Yusmaita, E. (2013). Konstruksi bahan ajar sel volta berbasis green chemistry education untuk membangun literasi sains siswa. Tesis, tidak dipublikasikan. Universitas Pendidikan Indonesia.

Zo'bi, A.S. (2014). The effect of using socioscientific issues approach in teachingenvironmental issues on improving the students' ability of making approriate decision towards these issues.International Education Studies, 9(8), 113-123. Retrieved fromhttp://files.eric.ed.gov/fulltext/EJ107 0436.pdf

Zeidler, D.L. \& Nichols, B.H. (2009). Socioscientific issues: theory and practices. Journal of Elementary Science Education, 21(2), 49-58. Retrieved fromhttp://files.eric.ed.gov/fulltext/EJ849 716.pdf 